\title{
Kandungan Peroksida Minyak Goreng Pada Pedagang Gorengan Di Wilayah Kecamatan Tembalang Kota Semarang
}

\section{Peroxide Content in Cooking Oil Used By Fritter Traders in Tembalang Sub- district Semarang City}

\author{
Dina Rahayuning Pangestuti*, Siti Rohmawati ${ }^{1}$
}

\begin{abstract}
ABSTRAK
Latar Belakang: Penggunaan minyak goreng secara berulang dapat mempengaruhi kualitas minyak dan komposisi zat gizi di dalamnya. Keberadaan peroksida dapat digunakan sebagai indikator kerusakan minyak. Gorengan merupakan makanan jajanan dengan menggunakan adonan tepung yang digoreng dengan minyak berlebih (deep fat frying) dan dijual di tepi jalan.

Tujuan: Penelitian ini bertujuan mendeskripsikan dan menganalisis jumlah nilai peroksida minyak goreng yang digunakan pedagang gorengan di Kecamatan Tembalang, Kota Semarang.

Metode: Jenis penelitian ini adalah deskriptif observasional. Sampel dalam penelitian ini sebanyak 25 yang didapatkan dari 25 pedagang gorengan. Data analisis univariat digunakan untuk menggambarkan distribusi frekuensi dan rerata. Analisis bilangan peroksida ditetapkan sesuai SNI 3741-2013.

Hasil: Penelitian menunjukkan bahwa $28 \%$ pedagang menggunakan minyak bermerek, sisanya berupa minyak curah. Minyak yang dibeli secara curah memiliki rerata peroksida $8,77 \mathrm{mEq} \mathrm{O}_{2} / \mathrm{kg}$, sedangkan bermerk $11,71 \mathrm{mEq} \mathrm{O}_{2} / \mathrm{kg}$.

Kesimpulan: Sebesar $44 \%$ minyak goreng melebihi jumlah peroksida maksimum ( $>10 \mathrm{mEq} \mathrm{O} / \mathrm{kg}$, SNI 3741-2013). Minyak curah mempunyai rerata nilai peroksida lebih rendah dibandingkan minyak bermerek.
\end{abstract}

Kata kunci: Peroksida, kerusakan minyak goreng, pedagang gorengan

\begin{abstract}
Background: The repeated use of cooking oil can affect the quality of the oil and the nutrient composition in it. The presence of peroxides can be used as an indicator of oil deterioration. Fritter food is snacks by using flour dough which was prepared by deep fat frying method and sold on the street lot.

Purpose: This study aimed to describe and analyze the amount of peroxide value of cooking oil used by fritter traders in Tembalang Sub-district, Semarang City.

Methods: This is an observational descriptive research which analyzed 25 samples of used cooking oil of 25 fritter traders. Univariate analysis data was used to describe frequency distribution and mean. Analysis of peroxide value was established according to SNI 3741-2013.

Results: Research shows that $28 \%$ of traders use branded oil, while the rest use bulk oil. Bulk purchased oil has an average peroxide of $8.77 \mathrm{mEq} \mathrm{O}_{2} / \mathrm{kg}$, while the branded $11.71 \mathrm{mEq} \mathrm{O}_{2} / \mathrm{kg}$.

Conclusions: Forty-four percent of cooking oil exceeds the maximum peroxide amount $>10 \mathrm{mEq} \mathrm{\textrm {O } _ { 2 }}$ $/$ kg, SNI 3741-2013). Bulk oil has a lower average peroxide content than branded oils.
\end{abstract}


Keywords: Peroxide, cooking oil deterioration, fritters traders

\author{
*Koresponden: \\ dina.putranadya@gmail.com \\ ${ }^{1}$ Fakultas Kesehatan Masyarakat, Universitas Diponegoro
}

\section{PENDAHULUAN}

Gorengan adalah makanan yang disajikan dengan cara digoreng menggunakan minyak berlebih atau disebut juga metode deep fat frying. Makanan jenis ini digemari oleh masyarakat Indonesia. Hal ini berdampak pada meningkatnya penggunaan minyak goreng di Indonesia. Berdasarkan Data Susenas 2012 menyebutkan bahwa konsumsi minyak goreng per kapita penduduk Indonesia pada tahun 2011 sebanyak 8,24 liter/tahun/kapita. ${ }^{1}$ Data Studi Diet Total di Propinsi Jawa Tengah pada tahun 2014 menunjukkan bahwa rerata konsumsi minyak, lemak dan olahan lainnya sebesar $42,2 \pm 45,5$ gram per orang per hari pada seluruh kelompok umur. Sebanyak hampir seluruh penduduk Propinsi Jawa Tengah menggunakan minyak kelapa sawit dan minyak kelapa dibandingkan olahan lainnya $(95,4 \%){ }^{2}$

Minyak goreng adalah lemak yang berbentuk cair pada suhu kamar.Minyak goreng merupakan bahan pangan dengan komposisi utama trigliserida yang berasal dari bahan nabati, dengan atau tanpa perubahan kimiawi dan telah melalui proses rafinasi atau pemurnian yang digunakan untuk menggoreng. Selama penggorengan terjadi hidrolisa, oksidasi dan dekomposisi minyak yang dipengaruhi oleh bahan pangan dan kondisi penggorengan. ${ }^{3}$ Pada saat penggorengan, sebagian kecil minyak goreng akan diserap oleh bahan pangan yang digoreng, sehingga kualitas minyak goreng akan mempengaruhi cita rasa makanan yang digoreng. ${ }^{4}$

Minyak goreng akan mengalami kerusakan apabila digunakan secara lebih dari 2 kali penggorengan. Kerusakan minyak yang terjadi pada saat penggorengan meliputi oksidasi, polimerasi, dan hidrolisis. Penggunaan minyak goreng berulang kali mengakibatkan minyak menjadi rusak karena lemak tidak jenuh teroksidasi membentuk lipid peroksida. ${ }^{5}$ Salah satu parameter penurunan mutu minyak goreng adalah jumlah bilangan peroksida. Pada minyak goreng, angka peroksida menunjukkan ketengikan minyak goreng akibat proses oksidasi serta hidrolisis. Penetapan jumlah bilangan peroksida dapat dilakukan dengan menggunakan metode titrasi iodometri. ${ }^{6}$

Kerusakan minyak akan mempengaruhi mutu dan nilai gizi bahan pangan yang digoreng serta dapat berdampak pada kesehatan. Konsumsi minyak yang mengandung peroksida akan membentuk radikal bebas di dalam tubuh. Radikal bebas merupakan senyawa yang berbahaya bagi kesehatan tubuh karena dapat menyebabkan kerusakan DNA sel, kematian sel dan berpotensi menimbulkan kanker. Radikal bebas dapat memicu terjadinya kanker paru, kanker kulit, kanker kolon dan kanker esophagus. ${ }^{7}$ Artinya, banyak mengkonsumsi makanan berminyak yang mengandung tinggi peroksida dapat berbahaya bagi kesehatan tubuh.

Kecamatan Tembalang Kota Semarang merupakan salah satu wilayah yang ada di kota Semarang, Jawa Tengah. Di wilayah ini terdapat cukup banyak pedagang yang berjualan gorengan. Berdasarkan hasil survei pendahuluan, terdapat sekitar 30 pedagang gorengan yang berlokasi di pinggir jalan. Para pedagang gorengan tersebut menggunakan minyak goreng secara berulang-ulang, bahkan hingga minyak berwarna hitam. Padahal minyak goreng yang berwarna hitam sudah tidak layak untuk digunakan kembali. Hal ini terjadi juga disebabkan karena belum adanya pengawasan mengenai ketengikan pada minyak goreng di pedagang kaki lima oleh Badan Pengawas Obat dan Makanan (BPOM). Oleh sebab itu, perlu adanya pengawasan yang lebih ketat untuk menjaga keamanan 
pangan dan kualitas gizi makanan yang dijual di pinggir jalan sehingga dapat menjaga status gizi dan kesehatan masyarakat.

Penelitian ini bertujuan untuk mendeskripsikan dan menganalisis jumlah bilangan peroksida pada minyak goreng yang digunakan oleh para pedagang gorengan di Kecamatan Tembalang Kota Semarang. Hasil pengujian bilangan peroksida pada minyak goreng kemudian dibandingkan dengan Standar Mutu Minyak Goreng SNI nomor 013741-2013.

\section{METODE}

Desain penelitian ini adalah deskriptif observasional dengan populasi berupa minyak goreng yang digunakan pedagang gorengan yang berjualan di pinggir jalan di wilayah Kecamatan Tembalang Kota Semarang. Teknik pengambilan sampel pada penelitian ini menggunakan total sampling. Terdapat 30 orang pedagang yang menjual gorengan, namun hanya 25 orang yang bersedia diambil sampel minyak goreng yang dipakai. Wawancara dengan kuesioner dilakukan pula untuk mengumpulkan data terkait dengan karakteristik pedagang, yaitu usia, jenis kelamin, pendidikan terakhir dan jangka waktu berdagang gorengan. Wawancara hanya dapat dilakukan terhadap 18 orang pedagang, sedangkan 7 orang lainnya menolak. Sampel yang diambil untuk diteliti diambil dari wajan penggorengan yang digunakan sebanyak $\pm 100 \mathrm{ml}$ minyak goreng per pedagang. Sampel minyak ditempatkan pada botol kaca bertutup, dilakukan pencatatan suhu, jenis bahan yang digoreng dan frekuensi penggunaan minyak saat dilakukan pengambilan sampel tersebut. Pengukuran suhu minyak dilakukan dengan menggunakan thermometer makanan digital merk KIMO.

Penentuan bilangan peroksida sampel dilakukan menggunakan uji peroksida dengan metode iodometri. Uji peroksida dilakukan di Laboratorium Gizi Kesehatan Masyarakat Fakultas Kesehatan Masyarakat Universitas Diponegoro, Semarang. Prinsip penentuan peroksida dengan menggunakan metode titrasi yaitu berdasarkan pada pengukuran sejumlah lod yang dibebaskan pada kalium lodida melalui reaksi oksidasi oleh peroksida dalam minyak pada suhu ruang di medium kloroform atau asam asetat. Prosedur penentuan bilangan peroksida berdasarkan SNI 01-3741-2013. ${ }^{8}$

Analisis data dengan menggunakan analisis univariat yang menghasilkan distribusi frekuensi dan persentase dari variabel. Hasil dalam penelitian ini meliputi hasil secara deskriptif dengan menggunakan tabel distribusi frekuensi, mean dan median.

\section{HASIL DAN PEMBAHASAN}

Pada penelitian ini, pedagang gorengan menggunakan 2 jenis minyak goreng yaitu minyak goreng dengan kemasan premium dan bermerek, yang dibeli di swalayan sekitar lokasi berjualan dan minyak goreng yang dibeli di pasar dengan kemasan plastik, tanpa merek (curah). Berdasarkan Tabel 1. diketahui bahwa hampir semua pedagang menggunakan jenis minyak goreng curah. Minyak goreng sangat mudah untuk mengalami oksidasi. Oleh sebab itu, minyak goreng yang digunakan berulang kali atau disebut juga minyak jelantah telah mengalami penguraian molekulmolekul, sehingga titik asapnya pun menurun, dan apabila disimpan lebih lama lagi dapat menyebabkan minyak menjadi berbau tengik. Bau tengik dapat terjadi karena penyimpanan yang salah dalam jangka waktu tertentu menyebabkan pecahnya ikatan trigliserida menjadi gliserol dan FFA (free fatty acid) atau asam lemak jenuh. ${ }^{9,10}$

Kerusakan lemak atau minyak yang utama adalah karena peristiwa oksidasi dan hidrolitik, baik enzimatik maupun non enzimatik. Hasil yang diakibatkan oksidasi lemak antara lain peroksida, asam lemak, aldehid dan keton. Bau tengik atau rancidity terutama disebabkan oleh aldehid dan keton. Tingkat kerusakan minyak dapat diketahui dengan bilangan peroksida atau angka thiobarbiturat. ${ }^{10,11}$

Berdasarkan hasil penelitian, rerata bilangan peroksida pada minyak goreng hampir mendekati batas maksimal bilangan peroksida pada minyak goreng (Tabel 1). Menurut SNI nomor 3741 tahun 2013, batas 
Tabel 1. Karakteristik dan Bilangan Peroksida minyak goreng dari pedagang gorengan di Wilayah Kecamatan Tembalang Kota Semarang

\begin{tabular}{|c|c|c|c|}
\hline Variabel & Satuan & Rerata \pm SD & Minimum-Maximum \\
\hline Suhu saat pengambilan sampel & ${ }^{\circ} \mathrm{C}$ & $124,5 \pm 42,5$ & $46,9-177,1$ \\
\hline Frekuensi pakai & Kali & 1 & $1-2$ \\
\hline Bahan makanan yang digoreng & $N(\%)$ & & \\
\hline Tahu & & $6(24)$ & \\
\hline Tempe & & $10(40)$ & \\
\hline Bakwan & & $1(4)$ & \\
\hline Ubi & & $1(4)$ & \\
\hline $\begin{array}{lcr}\text { Campuran } & \text { (sisa penggorengan } & \text { sehari } \\
\text { sebelum } & \text { pengambilan } & \text { sampel } \\
\text { penelitian) } & & \end{array}$ & & $7(28)$ & \\
\hline Jenis minyak & $N(\%)$ & & \\
\hline Curah & & $18(72)$ & \\
\hline Bermerek & & $7(28)$ & \\
\hline Bilangan Peroksida & $\mathrm{mEq} \mathrm{O}_{2} / \mathrm{Kg}$ & $9,59 \pm 3,47$ & $3,59-16,91$ \\
\hline Curah $^{\mathrm{a}}$ & & $8,77 \pm 3,49$ & $3,59-16,91$ \\
\hline Bermerek & & $11,72 \pm 2,49$ & $8,63-15,47$ \\
\hline
\end{tabular}

${ }^{\mathrm{a} B}$ Berbeda signifikan antara minyak curah dengan minyak bermerek, Uji Mann-Whitney, $p$ value $=0,026<0,05$

maksimal bilangan peroksida adalah $10 \mathrm{mEq}$ $\mathrm{O}_{2} / \mathrm{Kg}$.Sebanyak 11 dari 25 sampel minyak goreng memiliki jumlah bilangan peroksida lebih dari $10 \mathrm{mEq} \mathrm{O} / \mathrm{Kg}$. Artinya, $44 \%$ minyak goreng yang digunakan telah rusak, hal ini ditunjukkan dengan peningkatan bilangan peroksida pada sampel minyak goreng.Salah satu penyebab kenaikan bilangan peroksida adalah minyak goreng yang digunakan berkalikali oleh para pedagang.

Penelitian yang menggunakan pula minyak sawit sebagai minyak untuk menggoreng kerupuk menemukan bahwa penggorengan sebanyak 5 kali dapat meningkatkan bilangan peroksida minyak sawit, yaitu 4,84 $\mathrm{mEq} \quad \mathrm{O}_{2} / \mathrm{Kg}$ pada penggorengan pertama dibandingkan dengan $14,26 \mathrm{mEq} \mathrm{O} / \mathrm{Kg}$ pada penggorengan ke $5 .{ }^{12}$ Selain itu, penyimpanan minyak goreng tidak dilakukan secara tertutup, sehingga dapat mempengaruhi kandungan peroksida pada minyak goreng akibat kontak dengan udara luar. Faktor penyimpanan minyak goreng seringkali kurang diperhatikan oleh pedagang.

Pada prinsipnya, proses oksidasi minyak dapat terjadi selama penyimpanan melalui reaksi autooksidasi dan oksidasi fotosintesis. Konsentrasi dan jenis oksigenmempengaruhi terjadinya oksidasi dalam minyak, dalam bentuk triplet oksigen $\left({ }^{3} \mathrm{O}_{2}\right)$ dan singlet oksigen $\left({ }^{1} \mathrm{O}_{2}\right)$ dari udara. Terjadinya oksidasi pada minyak meningkat seiring dengan meningkatnya jumlah oksigen yang terlarut dalam minyak. Kemudahan untuk bereaksi dengan minyak ditentukan pula oleh proporsi jenis oksigen yang terlarut dalam minyak. Singlet oksigen lebih mudah dan lebih cepat bereaksi dengan minyak, sedangkan triplet oksigen bereaksi dengan radikal bebas. ${ }^{13}$

Pada penelitian ini, jumlah bilangan peroksida paling tinggi yaitu sebesar 16,91 $\mathrm{mEq} \mathrm{O}_{2} / \mathrm{Kg}$ terdapat pada sampel dengan jenis minyak goreng curah. Namun demikian, rerata bilangan peroksida minyak bermerek lebih tinggi dibandingkan minyak goreng curah. Rerata bilangan peroksida minyak goreng curah pada penelitian ini adalah $8,77 \mathrm{mEq}$ $\mathrm{O}_{2} / \mathrm{Kg}$, sedangkan rerata pada minyak goreng bermerek adalah $11,77 \mathrm{mEq} \mathrm{O}_{2} / \mathrm{Kg}$. Jumlah sampel yang memiliki kandungan peroksida diatas standar SNI lebih banyak terjadi pada minyak goreng bermerek (Gambar 1). Pada minyak goreng bermerek telah melalui proses penjernihan berulang dan kemungkinan berbeda jumlah tahapan penjernihannya dibandingkan dengan minyak goreng curah. Penyebab ketidakstabilan oksidatif pada minyak dapat disebabkan oleh metode selama proses pengolahan minyak. Pada minyak mentah (crude oil), perlakuan penyaringan dan penjernihan (bleaching) lebih minimal dibandingkan dengan minyak yang mengalami 


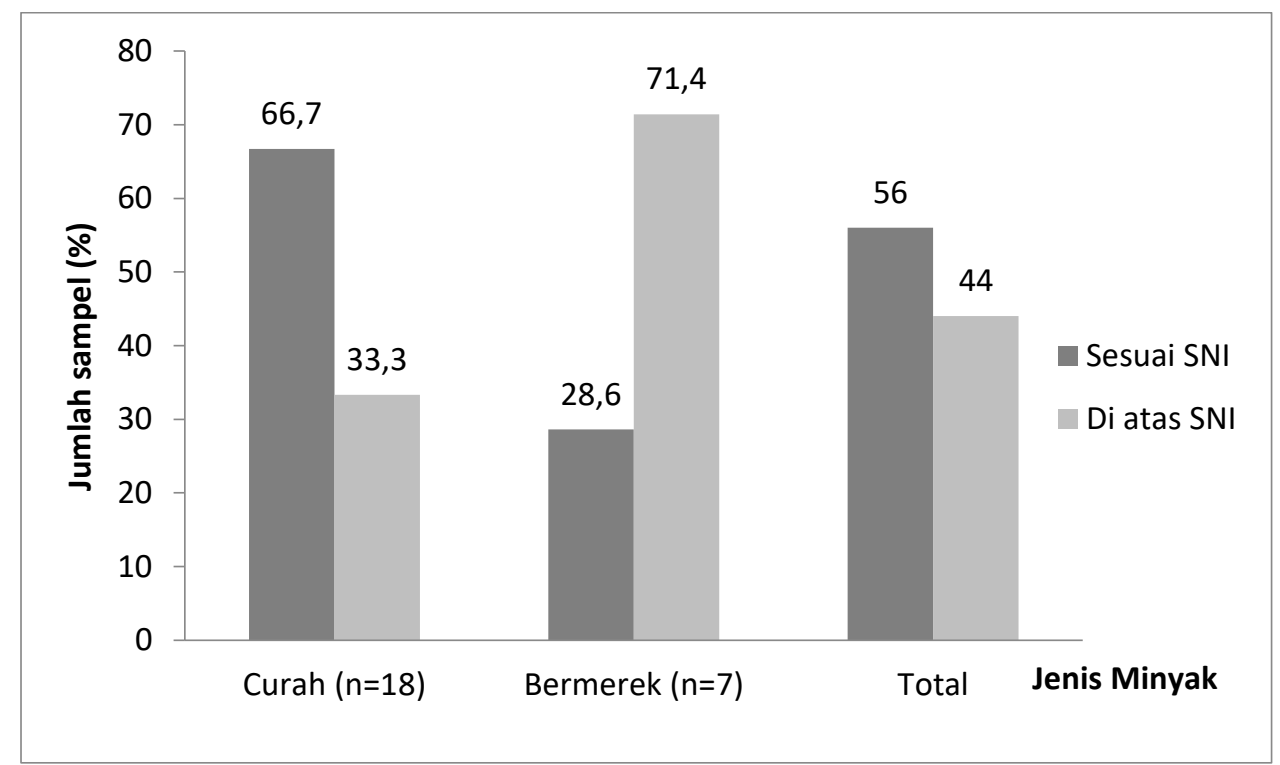

Gambar 1. Persentase sampel minyak goreng yang memenuhi dan tidak memenuhi standar SNI (> $10 \mathrm{mEq} \mathrm{O}_{2} / \mathrm{kg}$ )

proses tersebut (refined oil). ${ }^{13}$ Namun demikian, penelitian ini tidak meneliti secaraseksama proses penjernihan pada kedua jenis sampel tersebut. Faktor lain yang tidak diteliti adalah jumlah bilangan peroksida di awalsebelum digunakan menggoreng oleh para pedagang gorengan.

Pada penelitian dengan sampel minyak goreng curah tanpa merek dan berfortifikasi vitamin A, bilangan peroksida pada awal penelitian berkisar dibawah $2 \mathrm{mEq} \mathrm{O}_{2} / \mathrm{kg}, 4$ $\mathrm{mEq} \mathrm{O}_{2} / \mathrm{kg}$ dan $9 \mathrm{mEq} \mathrm{O} / \mathrm{kg}$. Perlakuan yang diberikan adalah berupa perbedaan suhu penyimpanan pada 60,75 dan $90^{\circ} \mathrm{C}$ dan kemudian diukur kandungan peroksida serta umur simpannya. Penelitian tersebut menemukan bahwa minyak dengan kandungan peroksida awal tergolong tinggi akan memperpendek umur simpan minyak dan bilang peroksida lebih cepat mencapai batas yg dianjurkan oleh SNI yaitu $10 \mathrm{mEq}$ $\mathrm{O}_{2} / \mathrm{kg}$. Selain itu, penyimpanan pada suhu tinggi dapat pula menurunkan masa simpan minyak goreng sebagai akibat meningkatnya pula kandungan peroksida dalam minyak goreng. ${ }^{14}$

Tingginya bilangan peroksida dapat pula dipengaruhi oleh faktor lain, yaitu jenis minyak goreng (berkaitan dengan komposisi asam lemak penyusun minyak), lama pemanasan, dan suhu pemanasan. Pada suhu lebih dari $100^{\circ} \mathrm{C}$, asam lemak jenuh pada minyak akan teroksidasi.Suhu yang tinggi selama penggorengan akan mempercepat proses oksidasi pada minyak dan proses oksidasi akan menurun apabila suhu turun. ${ }^{13,15}$ Pada penelitian ini, rerata suhu yang tercatat saat pengambilan sampel dapat dijadikan sebagai gambaran umum suhu yang digunakan, yaitu sebesar $124,5 \pm 42,5^{\circ} \mathrm{C}$ dan suhu maksimal mencapai $177,1^{\circ} \mathrm{C}$. Pada penelitian di Tanzania dengan sampel minyak kelapa sawit menunjukkan terdapat perubahan bilangan peroksida yang signifikan dibadingkan dengan awal $\left(0,19 \mathrm{mEq} \mathrm{O}_{2} / \mathrm{kg}\right)$. Pemanasan pada suhu $120^{\circ} \mathrm{C}$ selama 60 hari dengan lama pemanasan setiap harinya adalah 3 jam dapat meningkatkan bilangan peroksida sebesar $26,81 \pm 0,33 \mathrm{mEq} \mathrm{O} / 2 \mathrm{~kg} .{ }^{16}$

Minyak goreng yang mengandung tinggi bilangan peroksida dapat menyebabkan kerusakan pada zat gizi makanan yang digoreng serta dapat berdampak pada kesehatan. Pada minyak goreng yang mengandung tinggi peroksida akan menurunkan stabilitas kandungan vitamin $A$ yang difortifikasi pada minyak goreng. ${ }^{5,14}$ Hasil penelitian Andarwulan dkk menunjukkan bahwa penurunan kandungan vitamin $A$ terjadi pada minyak goreng sawit yang 
memiliki kandungan peroksida $9 \mathrm{mEq} \mathrm{O}_{2} / \mathrm{kg}$ pada awal penelitian. ${ }^{14}$ Penurunan kandungan vitamin $A$ dapat mengindikasikan pula terjadinya peningkatan kandungan peroksida dalam minyak goreng, baik yang pada awalnya mengandung sedang (mildly) atau tinggi (highly) kandungan peroksida. ${ }^{17}$

Penelitian dengan menggunakan tikus Wistar yang diberikan perlakuan pemberian minyak goreng yang dipanaskan berulang hingga 3 kali dibandingkan dengan yang hanya digunakan 1 kali menunjukkan bahwa terdapat kerusakan yang lebih signifikan pada jejunum, usus besar dan liver pada kelompok tikus yang diberi minyak goreng digunakan berulang 3 kali. Terdapat peningkatan level enzim yang berperan sebagai antioksidan terjadi pada tikus tersebut sebagai respon atas terjadinya stress oksidatif. Hal ini disebabkan oleh terbentuknya Reactive Oxygen Species (ROS). Analisis pada sampel darah juga menunjukkan peningkatan glukosa, kreatinin dan kolesterol dengan seiring penurunan level protein dan albumin pada tikus yang diberi pakan minyak goreng dengan penggorengan berulang. ${ }^{18}$

Tabel 2. Karakteristik pedagang gorengan di Wilayah Kecamatan Tembalang Kota Semarang

\begin{tabular}{lcc}
\hline \multicolumn{1}{c}{ Variabel } & Satuan & Nilai \\
\hline $\begin{array}{l}\text { Rerata usia } \\
\text { Jenis Kelamin }\end{array}$ & Tahun & $39,5 \pm 3$ \\
$\begin{array}{l}\text { Laki-laki } \\
\text { Perempuan }\end{array}$ & $\mathrm{N}(\%)$ & $8(44,4)$ \\
& & 10 \\
Pendidikan terakhir & $\mathrm{N}(\%)$ & $(55,6)$ \\
Tidak tamat SD & & $2(11,1)$ \\
SD & & $5(27,8)$ \\
SMP & & $5(27,8)$ \\
SMU & $6(33,3)$ \\
$\begin{array}{l}\text { Rerata jangka waktu } \\
\text { berjualan }\end{array}$ & Bulan & $79 \pm 20$ \\
\hline
\end{tabular}

Mengingat rerata kandungan bilangan peroksida pada penelitian ini tergolong tinggi atau hampir mendekati batas yang dianjurkan oleh pemerintah, maka yang dapat dilakukan oleh pedagang gorengan sebagai upaya untuk menahan laju kerusakan minyak goreng yang digunakan antara lain adalah faktor penyimpanan minyak goreng, baik yang belum digunakan maupun sisa minyak yang

digunakan sehari sebelumnya, pada tempat tertutup dan kedap cahaya matahari, serta frekuensi penggantian minyak goreng dengan yang baru dapat dilakukan dengan jangka waktu lebih pendek.

Berdasarkan wawancara dengan pedagang gorengan, sebagian besar telah berjualan gorengan lebih dari 5 tahun (Tabel 2). Apabila pengetahuan mengenai pentingnya keamanan pangan terutama penggunaan minyak goreng yang aman untuk produk gorengan serta dampaknya bagi kesehatan tidak diketahui, maka semakin banyak konsumen yang mengkonsumsi senyawa peroksida dari gorengan.

\section{KESIMPULAN}

Hasil uji peroksida menyatakan bahwa $44 \%$ minyak goreng melebihi batas maksimal bilangan peroksida ( $>10 \mathrm{mEq} \mathrm{O}_{2} / \mathrm{Kg}$, SNI 37412013). Minyak curah mempunyai rerata nilai peroksida lebih rendah dibandingkan minyak bermerek.

\section{ACKNOWLEDGMENT}

Penulis mengucapkan terimakasih kepada pedagangan gorengandi wilayah Kecamatan Tembelang Jawa Tengah yang telah bersedia menjadi responden dan meluangkan waktu dalam penelitian, serta kepada Fakultas Kesehatan Masyarakat, Universitas Diponegoro telah memberikan kontribusi kepada penelitian ini tercapai.

\section{REFERENSI}

1. Badan Pusat Statistik. Survei Sosial Ekonomi Nasional 2012. SocioEconomic/Monitoring Survey (2012).

2. Santoso, B., Sulistiowati, E., Fajarwati, T. \& Pambudi, J. Studi Diet Total: Survei Konsumsi Makanan Individu Provinsi Jawa Tengah 2014. Badan Penelitian dan Pengembangan Kesehatan (2014). doi:978-602-1099-31-5

3. Chatzilazarou, A., Gartzi O., Lalas, S., Zoidis, E., Tsaknis, J. Physicochemical 
Changes of Olive Oil and Selected Vegetable Oil during frying. J. Food Lipids13, 27-35 (2006).

4. Aladedunye, F. A. \& Przybylski, R. Degradation and Nutritional Quality Changes of Oil During Frying. J. Am. Oil Chem. Soc.86, 149-156 (2009).

5. Falade, A. O. \& Oboh, G. Thermal oxidation induces lipid peroxidation and changes in the physicochemical properties and $\beta$-carotene content of arachis oil. Int. J. Food Sci.2015, 1-7 (2015).

6. Pomeranz, Y. \& Meloan, C. E. Food analysis: theory and practice. Food analysis: theory and practice. (1994).

7. Mozaffarian, D. et al. Dietary intake of trans fatty acids and systemic inflammation in women. Am. J. Clin. Nutr.79, 606-612 (2004).

8. Badan Standardisasi Nasional. Minyak goreng. (Badan Standardisasi Nasional, 2013).

9. Ketaren, S. Pengantar Teknologi Minyak dan Lemak Pangan. (UI Press, 2012).

10. Mariod, A., Matthäus, B., K., Eichner., Hussein, I. . Frying quality and oxidative stability of two unconventional oils. J. Am. Oil Chem. Soc.83, 529-538 (2006).

11. Bukola, A.O.C., Francis, G.A., Patience, A., Olalekan, O. . Effects of Different Storage Temperature on the Physicochemical Properties of Cooking Oils Available in Nigeria Markets. Eur. J. Acad. Essays ISSN2, 7-14 (2015).

12. Kamisah, Y., Shamil, S., Nabillah, M.J., Kong, S. Y. \& Hamizah, N.A.S., Qodriyah, H.M.S., Azlina, M.F.N., Azman, A.,
Jaarin, K. Deep-fried keropok lekors increase oxidative instability in cooking oils. Malaysian J. Med. Sci.19, 58-63 (2012).

13. Choe, E., Min, D. . Mechanisms and Factors for Edible Oil Oxidation. Compr. Rev. Food Sci. Food Saf.5, 169-186 (2006).

14. Andarwulan, N., Gitapratiwi, D., Laillou, A., Fitriani, D., Hariyadi, P., Regina, M.P., Martianto, D. Quality of vegetable oil prior to fortification is an important criteria to achieve a health impact. Nutrients6, 5051-5060 (2014).

15. Pavlovska, G., Shurkova, N., Jankuloska, V. Oxidative stability of refined sunflower oil at room temperature and during conventional frying. Food Environ. Saf. J.16, 29-33 (2017).

16. Ngassapaa, F.N., Nyandoroa, S.S., Mwaisakab, T. . Effects of Temperature on the Physicochemical Properties of Traditionally Processed Vegetable Oils. Tanz. J. Sci38, 166-175 (2012).

17. Pignitter, M., Dumhart, B., Gartner, S., Jirsa, F., Steiger, G., Kraemer, K., Somoza, V. Vitamin A Is Rapidly Degraded in Retinyl Palmitate-Fortified Soybean Oil Stored under Household Conditions. J. Agric. Food Chem.62, 7559-7566 (2014).

18. Rekhadevi, P.V., Rajagopal, S. Evaluation of the deleterious health effects of consumption of repeatedly heated vegetable oil. Toxicol. Reports3, 636643 (2016). 